\title{
Chromosomal localisation of a gene(s) for Turner stigmata on Yp
}

\author{
Tsutomu Ogata, Chris Tyler-Smith, Stuart Purvis-Smith, Gillian Turner
}

\begin{abstract}
Although recent cytogenetic and molecular studies in patients with Turner stigmata are consistent with a gene(s) for Turner stigmata being present on both $X p$ and $Y p$, the precise location has not been determined. In this report, we describe a phenotypically female infant with Turner stigmata and a partial $Y p$ deletion and review genotype-phenotype correlations of the putative Turner gene(s) in non-mosaic patients with $Y$ chromosome rearrangements resulting from chromosomal breakage at Yp or Yc (pericentromeric region). The results indicate that the putative Turner gene(s) on $Y p$ is located in the $Y$ specific region from interval $1 \mathrm{~A} 1 \mathrm{~A}$ to interval $2 \mathrm{~B}$. In addition, assessment of $\mathrm{ZFX} / \mathrm{ZFY}$ and RPS4X/RPS4Y in the context of the Turner gene(s) suggests that $\mathrm{ZFX} / \mathrm{ZFY}$ rather than RPS4X/RPS4Y could be a candidate gene for the Turner stigmata. ( $\mathcal{}$ Med Genet 1993;30:918-22)
\end{abstract}

Turner syndrome is associated with characteristic somatic features such as webbed neck, low posterior hair line, lymphoedema, and cubitus valgus. ${ }^{1-3}$ Since such Turner stigmata are frequently manifested by patients with $45, \mathrm{X}$, $46, \mathrm{X}, \mathrm{Xp}-$, and $46, \mathrm{X}, \mathrm{i}(\mathrm{Xq}),{ }^{3}$ it has been suggested that $\mathrm{Xp}$ carries a gene(s) for Turner stigmata which escapes $\mathrm{X}$ inactivation. ${ }^{4}$ In addition, Turner stigmata have also been reported in patients with $46, \mathrm{X}, \mathrm{Yp}-{ }^{3}$ indicating that $\mathrm{Yp}$ also contains a gene(s) for Turner stigmata. ${ }^{4}$ These findings imply that the gene(s) for Turner stigmata is shared by $\mathrm{Xp}$ and $\mathrm{Yp}$, and that haploinsufficiency of the gene(s) results in the development of Turner stigmata. ${ }^{4}$ Although patients with $46, \mathrm{X}, \mathrm{Xq}-$ also sometimes have Turner stigmata, ${ }^{3}$ this could be explained by assuming that the putative Turner gene(s) on Xp escapes $\mathrm{X}$ inactivation on normal $\mathrm{X}$ chromosomes but is prone to undergo $\mathrm{X}$ inactivation on structurally abnormal X chromosomes. ${ }^{5}$

The putative Turner gene(s) has been located in the sex specific regions of $\mathrm{Xp}$ and Yp. ${ }^{4}$ Although genes in the pseudoautosomal region (PAR) share homology between the $X$ and the $\mathrm{Y}$ chromosome and are expected to escape $\mathrm{X}$ inactivation, genetic evidence currently available argues against the Turner gene(s) being present in the PAR. It has been shown by cytogenetic and molecular studies that the putative Turner gene(s) on $\mathrm{Xp}$ is present in the middle part of Xp. ${ }^{45}$ It has also been shown that sex reversed patients with $46, \mathrm{XY}$ caused by an abnormal $\mathrm{Xp}$; Yp inter- change have Turner stigmata in the presence of two doses of the PAR ${ }^{6}$ However, the precise location of the Turner gene(s) in the sex specific regions has not been determined.

In this report, we describe a patient with Turner stigmata and a partial Yp deletion, and review genotype-phenotype correlations of the putative Turner gene(s) on Yp. In addition, the possibility that ZFX/ZFY and RPS4X/ RPS4Y could be the Turner gene(s) is discussed.

\section{Case report}

This phenotypic female infant was the $3200 \mathrm{~g}$ product of an uncomplicated term pregnancy and delivery. Physical examination at 1 month of age showed webbed neck, low posterior hair line, lymphoedema of the hands and feet, redundant skin folds, and hypoplastic toenails. External genitalia were completely feminine, and an abdominal ultrasound indicated the presence of a normal uterus and a gonadal structure in the place of the left ovary. Cardiac evaluation showed a small patent ductus arteriosus. The subsequent clinical course was completely uneventful, and her length was $82 \mathrm{~cm}$ at 18 months of age (50th centile). On the basis of the above findings, she was diagnosed as having characteristic Turner stigmata, but was free from apparent growth failure.

The non-consanguineous parents were clinically normal. The younger brother had a large right sided cystic hygroma at birth which was surgically removed at 5 months of age. However, he had no other Turner stigmata, including webbed neck, and exhibited normal male sex development and growth pattern.

\section{CYTOGENETIC STUDIES}

Chromosome analysis was performed on 170 peripheral blood lymphocytes of the patient and on 15 lymphocytes of the younger brother and the parents, using $\mathrm{G}$ banding, $\mathrm{C}$ banding, and $\mathrm{N}$ banding (Ag-NOR).

The karyotypes of the patient, the younger brother, and the father were $46, \mathrm{X}, \mathrm{Y}$ qs with no evidence of mosaicism. No structural abnormality was detected in the $\mathrm{Y}$ chromosome short arm of the patient. The mother's karyotype was $46, \mathrm{XX}$.

\section{MOLECULAR STUDIES}

Genomic DNA was extracted from peripheral leucocytes of the patient, the father, and normal subjects, and digested with EcoRI, TaqI, and Sst I. Southern transfer, probe hybridisa- 

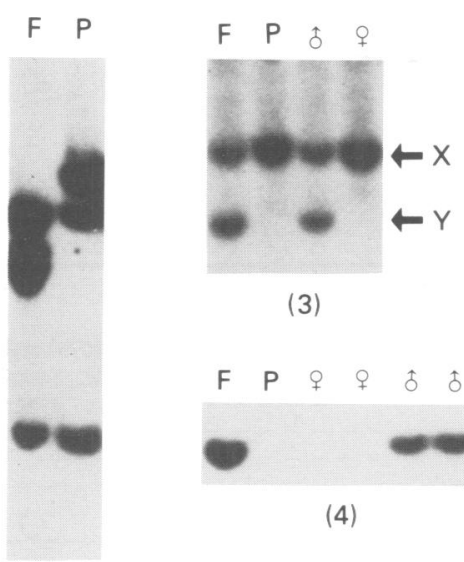

(3)

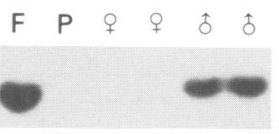

(4)
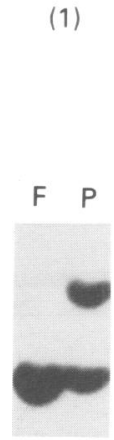

(2)

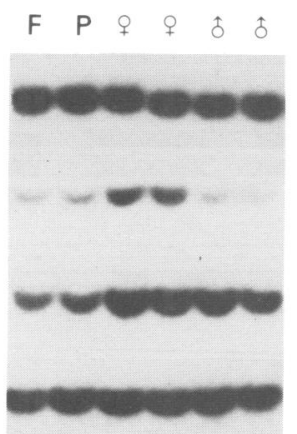

(5)
F $P$

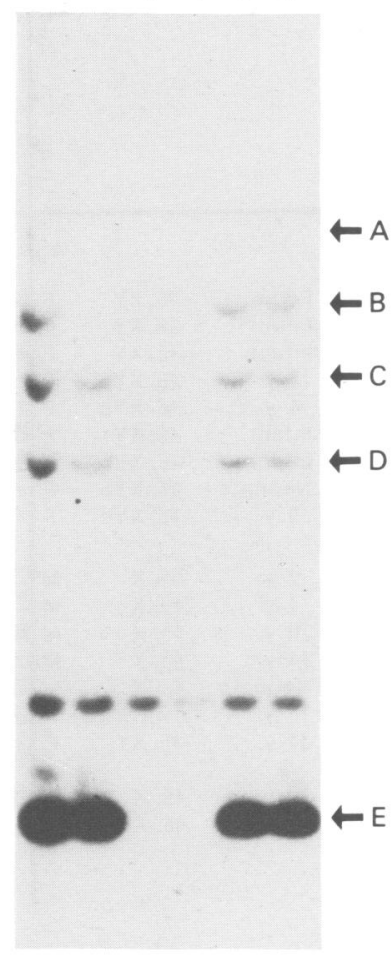

(6)

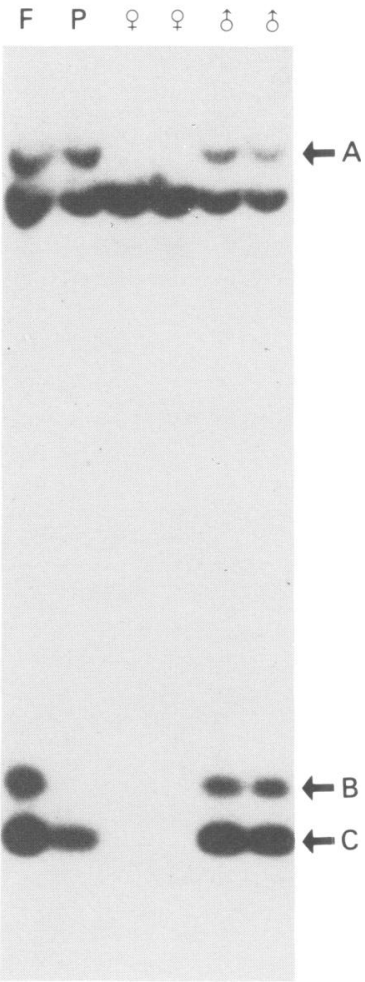

Figure 1 Southern blot analysis ( $F=$ father, $P=$ patient, $q=$ normal female, $\sigma^{*}=$ normal male). (1) EcoRI digests hybridised with 29C1 (DXYS14). The probe detects bands specific to the patient and to the father, together with those shared by them. (2) TaqI digests hybridised with 19B (MIC2). RFLP pattern shows the presence of two copies of MIC2 in the patient. (3) SstI digests hybridised with HfO.2 (PABX/PABY). PABY is absent in the patient, although PABX is present. (4) EcoRI digests hybridised with pY53.3 (SRY). The patient is negative for $S R Y$. (5) EcoRI digests hybridised with Hfo.2 (PABX/PABY) (top panel), M1A (DXS31) (second panel), pG15 (DXYS61) (third panel), and probe for autosomal TK gene as an internal control (bottom panel) (same filter; $N B$, the EcoRI filter is different from that used for $29 C 1, p Y 53.3,50 f 2$, and $52 d$ ). Band intensity ratios are $(F, P$, ㅇ, + , $\hat{o}, \hat{o}): P A B / T K(1.53,1 \cdot 67,1 \cdot 63,1 \cdot 45,1 \cdot 40,1 \cdot 52) ; D X S 31 / T K(0.15,0.18,0.35,0.30,0.12$, $0.09)$; and DXYS61/TK $(0.47,0.51,1 \cdot 15,1 \cdot 21,1.05,0.91)$. The results indicate that, in both the patient and the father, $P A B$ is present in two copies and DXS31 and DXYS61 are present in a single copy. (6) EcoRI digests hybridised with 50f2 (DYS7). DYS7/A and DYS7/B are absent in the patient. (7) EcoRI digests hybridised with $52 d$ (DYF27). The patient is negative for DYF27/B. Intensity ratio between DYF27/C band and the $X$ specific band (the second upper band) is 1.39 for the father, 0.74 for the patient, and 1.65 and 1.76 for the two control males, implying that one copy of DYF27/C in interval 3 is deleted whereas the other copy in interval 4 is preserved in the patient.

tion, and autoradiography were carried out by standard methods. The probes used were: (1) PAR: 29C1 (DXYS14), 113D (DXYS15), 601 (DXYS17), 19B (MIC2), and Hf0.2 (PABX/ PABY); (2) X specific region at Xp22.3: M1A (DXS31); (3) Y specific euchromatic region: pY53.3 (SRY), 27a (DYS104), GMGY3 (DYS13), $\quad$ MMF-1/pPB (ZFY), $\quad 47 Z$ (DXYS5Y), 50f2 (DYS7), 52d (DYF27), pDP34 (DXYS1Y), and p2F(2) (DYS25); and (4) Xqter-Yqter region: pG15 (DXYS61). (The references for the probes have been shown in the reports of Davies et $a l^{7}$ and Weissenbach and Goodfellow. ${ }^{8}$ ) Probe 50f2 detects five $\mathrm{Y}$ specific $E c o$ RI fragments designated A, B, C, D, and E. Probe 52d detects three $\mathrm{Y}$ specific EcoRI fragments designated $A, B$, and $C$; the $C$ fragment is a doublet, composed of one copy from interval 3 and the other copy from interval 4 (Tyler-Smith, unpublished data). Probe pG15 detects an Xqter-Yqter homologous locus. The copy number of X-Y homologous loci, DXS31, and DYF27/C was determined by the pattern of restriction fragment length polymorphisms or by the comparison of band intensity measured by a laser densitometer (Ultroscan, LKB).

Representative results are shown in fig 1 and summarised in fig 2 (case 6 ). In the patient, the $\mathrm{Y}$ specific loci from interval $1 \mathrm{~A} 1 \mathrm{~A}$ to interval 3 were deleted, whereas those assigned to interval 4 were preserved. Although PABY was absent, PABX was present in two copies as were other pseudoautosomal loci. DXS31 was present in a single copy. Both the patient and the father had a single copy of DXYS61, as expected from the cytogenetic findings of the Yqs chromosomes.

\section{Discussion}

The present study indicates that the Yqs chromosome of the patient is missing the $\mathrm{Y}$ specific region from interval $1 \mathrm{~A} 1 \mathrm{~A}$ to interval 3 , as a result of an abnormal $\mathrm{Xp}$; $\mathrm{Yp}$ interchange during paternal meiosis (fig 3 ). Although the $Y$ chromosomal PAR is also deleted, this is compensated for by the translocation of the $\mathrm{X}$ chromosomal PAR. These findings provide further evidence that the putative Turner gene(s) on $\mathrm{Yp}$ is located in the distal part of the $Y$ specific region rather than in the PAR. In addition, sex reversal is explained by the deletion of SRY, ${ }^{34}$ and normal growth is consistent with the pseudoautosomal growth gene(s) being present in two copies ${ }^{35}$ and gross chro- 


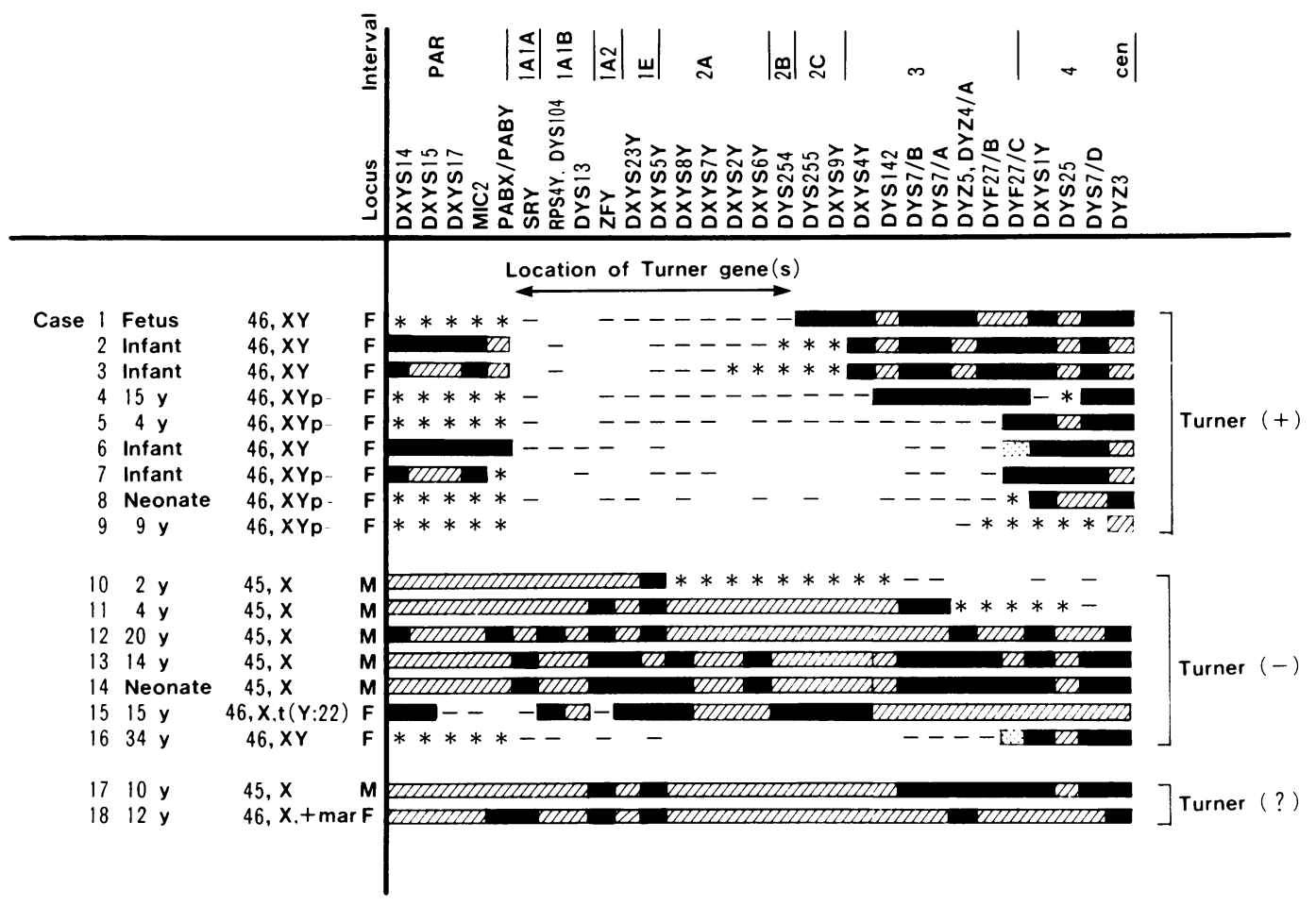

Figure 2 Genotype-phenotype correlations of the putative Turner gene( $s$ ) in non-mosaic patients with rearranged $Y$ chromosomes resulting from chromosomal breakage at $Y_{p}$ or Yc (pericentromeric region). Age, karyotype, and phenotypic sex ( $F=$ female, $M=$ male) are shown for each case (45, $X$ males have unbalanced $Y$; autosome translocations). References: case 1,910 cases 2 and 3,6 cases 4 and $5,^{10-14}$ case 6 present case, case $7,,^{15-17}$ case $8,,^{1012}$ case $9,{ }^{1418}$ case $10,{ }^{1920}$ case $11,{ }^{21}$ case $12,{ }^{22}$ case $13^{1023-25}$ case $14,,^{1026}$ case $15,{ }^{102728}$ case $16,,^{131429}$ case $17,,^{3031}$ and case 18. ${ }^{32}$ (For cases 14, 16, and 17, unpublished data of Tyler-Smith have been included.) The Y chromosomal intervals are based on the deletion maps reported by Vollrath et al. ${ }^{10}$ Probes and sequence tagged sites defining each locus are shown in the reports of Weissenbach and Goodfellow and Vollrath et al. ${ }^{10}$ The locus order within the

pseudoautosomal region ( $P A R$ ) is derived from the physical map reported by Petit et al, ${ }^{33}$ and that within the $Y$ specific region is based on the deletion maps constructed by Vollrath et al, ${ }^{10}$ Affara et al, ${ }^{16}$ and Tyler-Smith (unpublished data). (However, the precise order remains to be determined for the intervals $2 A, 2 C, 3$, and 4 .) For the $Y$ specific region, the black segments represent the positive loci confirmed by molecular studies, the striped segments represent the presumably positive loci inferred from interpolation or cytogenetic findings, the minus symbols represent the negative loci confirmed by molecular studies, the open segments represent the presumably negative loci inferred from interpolation, cytogenetic findings, or sexual phenotype, and the asterisks represent the dosage unknown loci. The stippled segments for DYF27/C in cases 6 and 16 denote that the locus has been confirmed to be present in reduced band intensity. For the PAR, the black segments indicate the confirmed disomic loci, the striped segments indicate the presumably disomic loci, the minus symbols indicate the confirmed monosomic loci, the open segment indicates the presumably monosomic locus, and the asterisks indicate the dosage unknown loci (it is uncertain whether the Yp-chromosomes in cases 1, 4, 5, 8, 9, and 16 are formed by abnormal Xp; Yp interchanges or by simple deletions). The location of the putative Turner gene $(s)$ is shown by the arrow.

mosome imbalance being absent. ${ }^{36}$ Although our patient inherited the satellited Y chromosome from the father, the apparently normal phenotype of the father suggests that the structural abnormality of Yqs has no phenotypic effect.

For a more precise localisation of the putative Turner gene(s) on $\mathrm{Yp}$, it is useful to review genotype-phenotype correlations in persons with Y chromosome rearrangements resulting from chromosomal breakage at $\mathrm{Yp}$ or Yc (pericentromeric region). For this purpose, we surveyed published reports for informative patients using the following criteria: (1) analysis of the rearranged $\mathrm{Y}$ chromosomes by molecular studies; (2) absence of numerical or structural abnormalities of the $\mathrm{X}$ chromosome; (3) lack of demonstrable mosaicism; and (4) description of somatic features. Consequently, a total of 18 informative patients was identified (fig 2). Before the correlations, however, two matters should be considered, that is, the number of genes involved and problems inherent in phenotypic assessment.

The number of Turner genes is unknown, but there are some indicators. Most Turner stigmata can be classified into three groups: (1) features attributable to lymphatic stasis, such as webbed neck, low posterior hair line, rotated ears, lymphoedema, redundant skin, nail dysplasia, and characteristic dermatoglyphics; (2) those attributable to skeletal anomalies, such as short neck, micrognathia, cubitus valgus, and short metacarpals and metatarsals; and (3) those attributable to vascular dysplasia, such as cardiac anomalies and, possibly, renal malformations. ${ }^{2}$ Since lymphovascular and skeletal systems are derived from mesenchyme, disruption of mesenchymal development might lead to the various Turner stigmata. Alternatively, lymphatic malformation alone ${ }^{37}$ might cause the various Turner stigmata. The possible contribution of lymphatic malformation to skeletal anomalies has been speculated upon. ${ }^{38}$ In fact, skeletal anomalies are detectable in the regions where there is retention of lymphatic fluid. A potential relationship of lymphatic stasis to cardiac and renal malformations has also been suggested. ${ }^{239} 40$ Thus, despite the phenotypic diversity, Turner stigmata could most simply be explained as sequelae of an impairment of a 


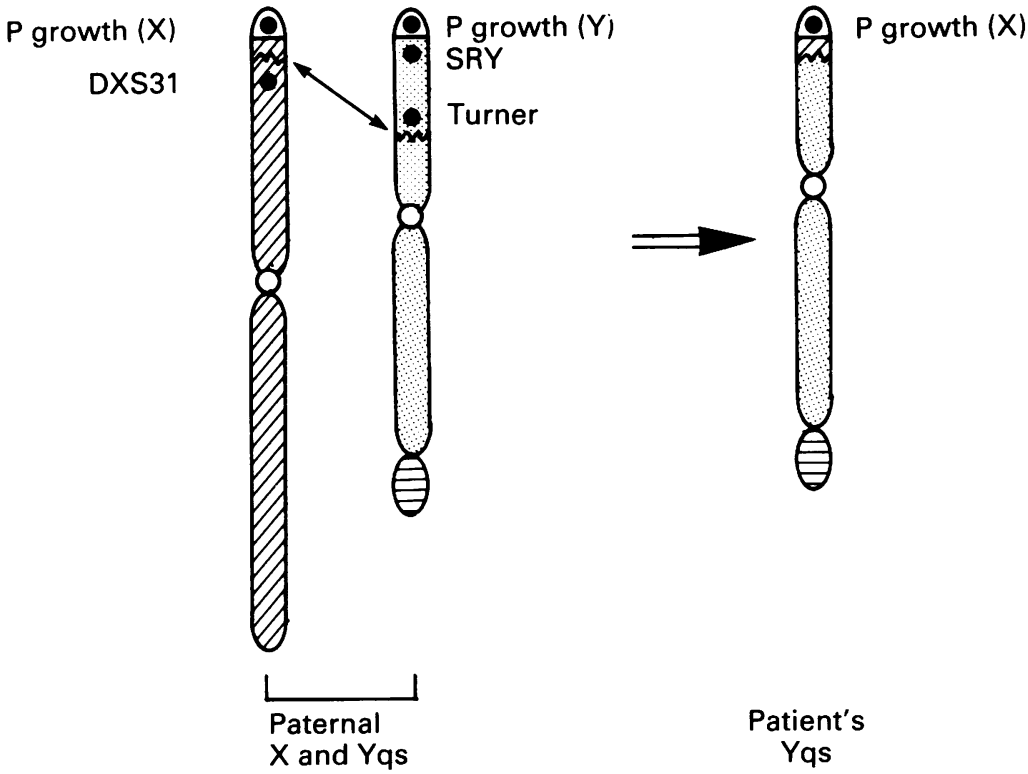

Figure $3 A$ schematic representation of the generation of the patient's Yqs chromosome. White, striped, and stippled areas depict the pseudoautosomal, $X$ specific, and $Y$ specific regions, respectively. The area indicated by horizontal lines denotes the chromosomal satellite. The patient's Yas chromosome was formed by an abnormal $X p ; Y p$ interchange during paternal meiosis, with the breakpoints being between $P A B X$ and $D X S 31$ in the $X$ specific region and at the border of intervals 3 and 4 in the $Y$ specific region. Consequently, SRY and the putative Turner gene (s) in the $Y$ specific region were lost, whereas the pseudoautosomal growth gene(s) was present in two doses. patients with characteristic Turner stigmata than in those with no or equivocal stigmata.

Genotype-phenotype correlations in 18 informative patients are shown in fig 2 . The simplest explanation is to assume a single Turner gene in the $\mathrm{Y}$ specific region from $1 \mathrm{~A} 1 \mathrm{~A}$ to $2 \mathrm{~B}$. This location is based on the results of cases 1 to 9 . All nine females had lymphoedema during fetal or infant life, three of them (cases, 4, 8, and 9) exhibited skeletal manifestations, and three of them (cases 1,6 , and 8) had cardiac or renal malformations. It might be possible that other Turner genes are present in the more proximal region. If this is the case, a gene(s) for lymphatic development is located in this region. The assignment is consistent with absent Turner stigmata in cases 10 to 15 , although lack of stigmata, especially in male patients with a partial autosomal monosomy, does not necessarily imply the presence of the Turner gene(s). The results of cases 16 to 18 may be confounding, but they do not provide direct evidence against the above location. The lack of Turner features in case 16 could be explained by assuming that expressivity was severely reduced or that some features remained undetected. Although case 17 has a high arched palate, short and slightly webbed neck, and shield chest, it is uncertain whether such non-characteristic or equivocal manifestations are directly caused by an impairment of the Turner gene(s). Rather, they could be the result of autosomal involvement. Although case 18 has a low hair line, high arched palate, pigmented naevi, and horseshoe kidney, the features also appear somewhat equivocal. In addition, latent mosaicism with a $45, \mathrm{X}$ cell line is possible in case 18 , since the patient has partial gonadal dysgenesis in the presence of SRY. Furthermore, it might be possible that, because of a cryptic complex deletion, the Turner gene(s) is preserved in case 16 and affected in cases 17 and 18 .

Two genes of unknown function, $\mathrm{ZFY}^{27}$ and RPS4Y, ${ }^{43}$ have been cloned from the region of the Turner gene(s). Both genes are associated with the homologous genes on the $\mathrm{X}$ chromosome, ZFX and RPS4X, which normally escape $X$ inactivation. ${ }^{434}$ Since $Z F X$ is present at Xp21.3-Xp22.1, ${ }^{44}$ the position of $\mathrm{ZFX} / \mathrm{ZFY}$ appears to satisfy the condition for the chromosomal location of the Turner gene(s). Although Page et $a l^{28}$ have reported that a female with 46,X,t(Y;22) missing ZFY (case 15) has no Turner stigmata, and Hecht et $a l^{45}$ have described a female with $46, \mathrm{X}, \mathrm{t}(\mathrm{X} ; \mathrm{Y})(\mathrm{p} 11.2 ; \mathrm{q} 11)$ and no apparent Turner stigmata, the findings based on the patients lacking Turner stigmata would not provide compelling evidence against ZFX/ZFY being the Turner gene. Since, to our knowledge, there has been no report documenting a patient with characteristic Turner stigmata in the presence of two copies of ZFX/ ZFY, the possibitity that ZFX/ZFY could be a candidate Turner gene has not been excluded formally. By contrast, RPS4X/RPS4Y is unlikely to be the Turner gene. The position of RPS4X at $\mathrm{Xq13}^{43}$ is inappropriate for the Turner gene. Furthermore, Just et al ${ }^{46}$ have reported that the transcription rate of RPS4X cult to assess accurately, even characteristic stigmata such as webbed neck and cubitus valgus. These caveats indicate that genotypephenotype correlations are more reliable in




is normal or increased in Turner patients with $46, \mathrm{X}, \mathrm{Xp}$ - and $46, \mathrm{X}, \mathrm{i}(\mathrm{Xq})$. Although detailed phenotypes are not described in the report, ${ }^{46}$ this would provide strong evidence against RPS4X/RPS4Y being the Turner gene.

In summary, although genotype-phenotype analysis of the putative Turner gene(s) on Yp is still not conclusive, we propose that the Turner gene(s) is located in the $\mathrm{Y}$ specific region from $1 \mathrm{~A} 1 \mathrm{~A}$ to $2 \mathrm{~B}$. In addition, assessment of ZFX/ZFY and RPS4X/RPS4Y in the context of the Turner gene(s) suggests that ZFX/ZFY rather than RPS4X/RPS4Y could be a candidate for the Turner gene.

We would like to thank Professor Peter Goodfellow for his critical comments, and Dr Alison Colley for the clinical information and blood collection.

1 Rosenfeld RG. Turner syndrome: a guide for physicians. Wayzala: The Turner's Syndrome Society, 1989.

2 Lippe BM. Physical and anatomical abnormalities in Turner syndrome. In: Rosenfeld RG, Grumbach MM, eds. Turner

3 Grumbach MM, Conte FA. Disorders of sexual differentiation. In: Wilson JD, Foster DW, eds. Williams' textbook tion. In: Wilson JD, Foster DW, eds. Williams textbook

4 Ferguson-Smith MA. Genotype-phenotype correlations in individuals with disorders of sex determination and deindividuals with disorders of sex determination and de-
velopment including Turner's syndrome. Semin Dev Biol velopment includi

5 Therman E, Susman B. The similarity of phenotypic effects caused by $\mathrm{Xp}$ and $\mathrm{Xq}$ deletions: a hypothesis. Hum Gene 1990;85:175-83.

6 Levilliers J, Quack B, Weissenbach J, Petit C. Exchange of terminal portions of $\mathrm{X}$ - and $\mathrm{Y}$-chromosomal short arms in human XY females. Proc Natl Acad Sci USA 1989;86:2296-300

7 Davies KE, Mandel JL, Monaco AP, Nussbaum RL, Willard HF. Report of the committee on the genetic constitution of the $\mathrm{X}$ chromosome. Cytogenet Cell Genet tion of the X

8 Weissenbach J, Goodfellow PN. Report of the committee on the genetic constitution of the $\mathrm{Y}$ chromosome. Cytoon the genetic constitution of the
genet Cell Genet 1991;58:967-85.

9 Benet Cell Genet 1991;58:967-85. Turner syndrome in an XY female fetus with deletion of
the sex-determining portion of the $\mathrm{Y}$ chromosome. $A m \mathcal{F}$ the sex-determining portion

10 Vollrath D, Foote S, Hilton A, et al. The human Y chromosome: a 43-interval map based on naturally occurring deletions. Science 1992;258:52-9.

11 Disteche CM, Casanova $\mathrm{M}$, Saal $\mathrm{H}$, et al. Small deletions of the short arm of the $\mathrm{Y}$ chromosome in 46,XY females. Proc Natl Acad Sci USA 1986;83:7841-4.

12 Cantrell MA, Bicknell JN, Pagon RA, et al. Molecular analysis of $46, \mathrm{XY}$ females and regional assignment of a analysis of $46, \mathrm{XY}$ females and regional assignment of a new Y-chrom

13 Muller U, Lalande M, Donlon TA, Heartlein MW. Breakage of the human Y chromosome short arm between two
blocks of tandemly repeated DNA sequences. Genomics blocks of tandem

14 Muller U, Fontaine D, Adinolfi M, Fraccaro M, Lalande $M$. Analysis of complex $Y$ chromosome aberrations using a single DNA probe (Y-367). Cytogenet Cell Genet 1989;50:161-4

15 Magenis RE, Tochen ML, Holahan KP, Carey T, Allen L, Brown MG. Turner syndrome resulting from partial deletion of the $\mathrm{Y}$ chromosome short arm: localization of male determinants. $\mathcal{F}$ Pediatr 1984;105:916-19.

16 Affara NA, Ferguson-Smith MA, Magenis RE, et al. Mapping the testis determinants by an analysis of $\mathrm{Y}$-specific sequences in males with apparent $\mathrm{XX}$ and $\mathrm{XO}$ karyotypes
and females with $\mathrm{XY}$ karyotypes. Nucleic Acids Res 1987;15:7325-42.

17 Casanova M, Cotinot C, Kirszenbaum M, Abbas N, Bishop $\mathrm{C}$, Fellous $M$. Characterization of human XX males and sexing of cattle embryos using $Y$-specific DNA sesexing of cattle embryos using Y-specific DNA se-
quences. In: Wachtel SS, ed. Evolutionary mechanisms in quences. In: Wachtel SS, ed. Evolutionary mechanisms in 18 Rosenfeld RG, Luzzatti L, Hintz RL, Miller OJ, Koo GC,
Wachtel SS. Sexual and somatic determinants of the human Y chromosome: studies in a $46, X Y p$-phenotypic fumas

19 Seidel H, Miller K, Spoljar M, Stengel-Rutkowski S. 45, X constitution in a $\mathrm{H}-\mathrm{Y}$ antigen positive boy with partial monosomy 5p. Clin Genet 1981;19:290-7.

20 Weber B, Schempp W, Orth U, Seidel H, Gal A. A Y/5 translocation in a $45, \mathrm{X}$ male with cri du chat syndrome. Hum Genet 1987;77:145-50.

21 Abbas N, Novelli G, Stella NC, et al. A 45,X male with molecular evidence of a translocation of $\mathrm{Y}$ euchromatin onto chromosome 1. Hum Genet 1990;86:94-8.

22 Arnemann J, Schnittger S, Hinkel GK, Tolkendorf E Schmidtke J, Hansmann I. A sterile male with $45, \mathrm{X} 0$ and a Y;22 translocation. Hum Genet 1991;87:134-8.

23 de la Chapelle A, Page DC, Brown L, Kaski U, Parvinen T, Tippett PA. The origin of 45,X males. Am 7 Hum Genet 1986;38:330-40.

24 Andersson M, Page DC, Pettay D, et al. Y;autosome translocations and mosaicism in the etiology of $45, \mathrm{X}$ maleness: assignment of fertility factor to distal Yq11. Hum Genet 1988;79:2-7.

25 Cantrell MA, Bogan JS, Simpson E, et al. Deletion mapping of $\mathrm{H}-\mathrm{Y}$ antigen to the long arm of the human $\mathrm{Y}$ chromosome. Genomics 1992;13:1255-60.

26 Munke M, Page DC, Brown LG, et al. Molecular detection of a $\mathrm{Yp} / 18$ translocation in a $45, \mathrm{X}$ holoprosencephalic male. Hum Genet 1988;80:219-23.

27 Page DC, Mosher R, Simpson EM, et al. The sex-determining region of the human $\mathrm{Y}$ chromosome encodes finger protein. Cell 1987;51:1091-104.

28 Page DC, Fisher EM, McGillivray B, Brown LG. Additional deletion in sex-determining region of human $Y$ chromosome resolves paradox of $\mathrm{X}, \mathrm{t}(\mathrm{Y} ; 22)$ female. Nature 1990;346:279-81.

29 Muller U, Kirkels VGHJ, Scheres JMJ. Absence of Turner stigmata in a 46,XYp- female. Hum Genet 1992;90:23942 .

30 Forabosco A, Carratu A, Assuma M, de Pol A, Dutrillaux B, Cheli E. Male with 45,X karyotype. Clin Genet B, Cheli E. Nal

31 Maserati E, Waibel F, Weber B, et al. A 45,X male with a Yp/18 translocation. Hum Genet 1986;74:120-32.

32 Fechner PY, Smith KD, Jabs EW, Migeon CJ, Berkovit GD. Partial gonadal dysgenesis in a patient with a marker Y chromosome. Am $\mathcal{F}$ Med Genet 1992;42:807-12.

33 Petit C, Levilliers J, Weissenbach J. Physical mapping of the human pseudo-autosomal region: comparison with genetic linkage map. EMBO f 1988;7:2369-76.

34 Sinclair AH, Berta P, Palmer MS, et al. A gene from the human sex-determining region encodes a protein with homology to a conserved DNA-binding motif. Nature 1990;346:240-4.

35 Ogata T, Petit C, Rappold G, Matsuo N, Matsumoto T, Goodfellow P. Chromosomal localisation of a pseudoauGoodfellow P. Chromosomal localisation of a pseudo

36 Ogata T, Matsuo N. Sex chromosome aberrations and stature: deduction of the principal factors involved in the determination of adult height. Hum Genet 1993;91:551 62 .

37 van der Putte SCJ. Lymphatic malformation in human fetuses: a study of fetuses with Turner's syndrome or status Bonnevie-Ullrich. Virchows Arch A Pathol Anat Histopathol 1977;376:233-46.

38 Lubin MB, Gruber HE, Rimoin DL, Lachman RS. Skeletal abnormalities in the Turner syndrome. In: Rosenfeld RG, Grumbach MM, eds. Turner syndrome. New York: Marcel Dekker, 1990:281-300.

39 Clark EB. Neck web and congenital heart defects: a pathogenic association in $45 \mathrm{X}-\mathrm{O}$ Turner syndrome? Teratology 1984;29:355-61.

40 Shepard TH, Fantel AG. Pathogenesis of congenital defects associated with Turner's syndrome: the role of hypoalbuminemia and edema. Acta Endocrinol 1986;suppl 279:440-7.

41 Ballard RA. Hydrops fetalis. In: Taeusch HW, Ballard RA, Avery ME, eds. Schaffer and Avery's diseases of the newborn. 6th ed. Philadelphia: Saunders, 1991:833-6.

42 Jones KL. Smith's recognizable patterns of human malformation. 4th ed. Philadelphia: Saunders, 1988

3 Fisher EM, Beer-Romero P, Brown LG, et al. Homologous ribosomal protein genes on the human $\mathrm{X}$ and $\mathrm{Y}$ chromosomes: escape from $X$ inactivation and possible implications for Turner syndrome. Cell 1990;63:1205-18.

44 Schneider-Gadicke A, Beer-Romero P, Brown LG, Nussbaum R, Page DC. ZFX has a gene structure similar to $\mathrm{ZFY}$, the putative human sex determinant, and escapes $\mathrm{X}$ inactivation. Cell 1989;57:1247-58.

45 Hecht T, Cooke HJ, Cerrillo M, Meer B, Reck G, Hameeister $\mathrm{H}$. A new case of $\mathrm{Y}$ to $\mathrm{X}$ translocation in a female. Hum Genet 1980;54:303-7.

46 Just W, Greekens C, Held KR, Vogel W. Expression of RPS4X in fibroblasts from patients with structural aberRPS 4 X in fibroblasts from patients with structural aber-
rations of the X chromosome. Hum Genet 1992;89:240-2. 